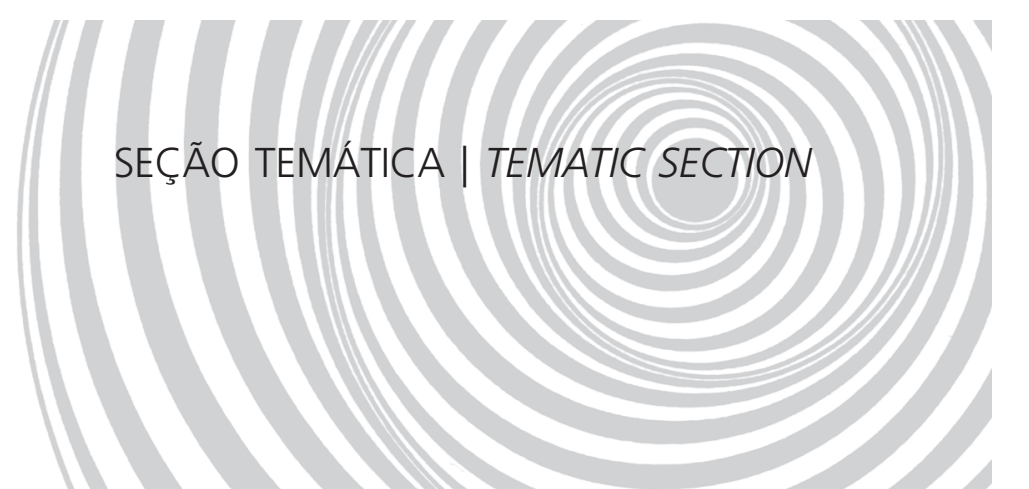

\title{
Representações iconográficas e literárias da produção de alimentos: espaços, atores e ideologias entre Antiguidade e Idade Média
}

\author{
The iconographic and literary representations of \\ food production: spaces, actors and ideologies \\ between Antiquity and Middle Ages
}

Giulia CRIPPA'

R E S U M O

Propõe-se um estudo iconográfico e literário do trabalho sazonal como ciclo produtivo, entre Antiguidade e Idade Média Tardia. Procurou-se estabelecer laços entre iconografias e economia e sociedade que as produziram. A representação auspiciosa prevalece, no panorama histórico das iconografias ligadas à previsão e à esperança de abundância. No âmbito da sociedade medieval elas estão fortemente atreladas ao tema da mudança das estações, da passagem cíclica temporal, do percurso de nascimento, morte e ressurreição. As representações dos trabalhos e das ocupações dos meses se transformam, e essa transformação é, muito mais que um reflexo, uma reflexão da sociedade sobre espaço e sobre atores do ciclo de produção alimentar. A Antiguidade legou à Idade Média uma variedade ampla de imagens fundamentadas, tanto na noção de personificação como de referências para as atividades ligadas aos ciclos sazonais, legado que será avaliado e modificado com base na nova experiência religiosa e social que permeia o período de maior presença dos ciclos dos meses ilustrados pelas atividades de produção do campo.

Termos de indexação: Iconografia. Ideologia. Imaginário. Literatura. Produção alimentar.

A B S T R A C T

An iconographic and literary study on seasonal work as productive cycle between antiquity and the late middle ages is proposed, looking for boundaries between the iconographies and economy and society that produced them. The auspicious representation prevails in the historical view of iconographies associated with the prediction and hope of abundance. Within the medieval society they are deeply bounded to main themes such as season changes, cyclic passage of time, journey through birth, death and resurrection. The representations of monthly work and activities change, and this change is much more than a mirror reflection, a reflection of society on the space and actors of the food production cycle. The legacy of antiquity to the middle ages is a

1 Universidade de São Paulo, Faculdade de Filosofia, Letras e Ciências. Av. dos Bandeirantes, 3900, 14040-901, Ribeirão Preto, SP, Brasil.E-mail: <giuliac@ffclrp.usp.br>. 
great amount of images based on notions of personification as well of reference for the activities associated with the seasonal changes, a legacy that will be assessed and changed based on the new social and religious experience. These permeate the century during which most of the month cycles illustrated by productive works in the field are produced.

Indexing terms: Iconography. Ideology. Imaginary. Literature. Food production.

\section{N T R O D U Ç Ã O}

A raiz simbólica que envolve o consumo de comida e bebidas é um fator constante das preocupações humanas. Comer e beber pertencem à esfera das necessidades fundamentais para a sobrevivência, mas desde sempre se revestem de valores simbólicos poderosos. Um campo fértil de imagens se entrelaça ao tema da produção de comidas e, por consequência, à riqueza e à opulência.

O tema se fundamenta na função representativa que a imagem ocidental conhece desde sua aparição: a representação das presas nas pinturas primitivas, com função propiciatória para a caça, é o primeiro elo de uma concepção ritual da presença do objeto traslado ou da reprodução visual que conhece as fases diversas do augúrio ou da maldição.

As implicações, encadeadas sem solução de continuidade da influência astral para o ciclo do ano, constituem o urdido para o imaginário compartilhado no Ocidente: desde a representação dos trabalhos dos calendários medievais, até as cenas de mercados, de cozinhas e de mesas postas, o percurso temático é relativamente contínuo.

As personificações dos meses por meio de suas representações nos trabalhos sazonais se tornam, a partir do século XII, topos iconográfico maciçamente disseminado na arte ocidental, como pode ser visto em Male ${ }^{1}$. As representações se encontram em lugares privilegiados como os portais das igrejas e os batistérios. A maioria de tais ilustrações parece se concentrar entre a península italiana e a França, com suas peculiaridades ligadas aos fatores climáticos diferentes. A presença em lugares de ampla visibilidade valoriza a mensagem do trabalho como inelutável e do destino mortal do homem, como também sua ressur- reição espiritual. Acima de tudo, reitera o ciclo imutável do tempo.

Para tentar compreender plenamente a origem e o valor das representações do ciclo de produção sazonal em um mundo rural é preciso voltar à tradição clássica.

As representações sazonais na arte cristã incorporam a disposição formal dos modelos antigos, mas os conteúdos amalgamam valores diversos das leituras formais, para explicitar as doutrinas teológicas da vida, da morte, da ressurreição de Cristo. O cristianismo interpretou o ciclo da produção e do consumo do campo como lição divina sobre acontecimentos e caducidade do homem.

Os modelos antigos sobrevivem na representação de atividades ligadas a alguns meses do ano, mas reformulados como alegorias cristãs e com conotações ideológicas explícitas. É o caso dos meses de Maio e Agosto, que apresentam com frequência figuras a cavalo ou caçando. Essas imagens se tornam os espaços das atividades nobres $^{2}$ no decorrer do tempo e com o fortalecimento de uma ideologia cortês.

\section{As tarefas do campo e o ciclo dos meses}

Varro, em seu De Re Rústica, falando do tema da produção agrícola, lembra que "Mais de cinqüenta são os autores gregos que escreveram dispersivamente de uma coisa ou de outra" ${ }^{3}$. Entre eles estão filósofos e historiadores, que escreveram em prosa e que, diz Varrone, estão ao alcance de todos. Na poesia também, continua o autor, existem obras sobre o assunto. Dos dois nomes que ele cita, Menécrates de Éfesos e Hesíodo de Ascra, este último adquiriu um peso maior na tradição. 
Os Erga, a composição de Hesíodo, oferecem um recorte imagético e fortemente ideológico da vida camponesa e dos valores atribuídos ao trabalho no campo no escorço do século VIII a.C.

Uma das razões pelas quais os Erga se mantêm objeto de reflexão em épocas sucessivas é a do valor atribuído ao trabalho, visto como resgate do homem na luta tenaz contra os elementos naturais, para obter os frutos da terra. Não se pode esquecer como, ao longo da Idade Média, o debate sobre a superioridade da vida contemplativa em relação à vida ativa tivera origens precoces ${ }^{4}$, em vista da necessidade de justificar o trabalho manual do qual decorria o sustento de todos e que, portanto, não podia ser liquidado simplesmente como punição contra o pecado de Adão. Os Erga, nesse sentido, ofereciam ótimas bases de discussão ${ }^{5}$.

O mundo camponês da Grécia do século VIII a.C. ainda possui papel de destaque, tanto jurídico como espiritual. Não se identifica, aqui, o âmbito de uma servidão sujeita a qualquer domínio. Muito pelo contrário, a integração desses agricultores e pastores livres gera os princípios da vida pública grega. Hesíodo se torna intérprete da ideologia do trabalho sazonal pelo filtro de suas tarefas cotidianas e, assim fazendo, inspira-se a uma ordem ideal do trabalho regulado pela Natureza e pelo ciclo sazonal para gerar fartura.

A segunda parte do poema é dedicada aos preceitos e às regras que presidem a economia doméstica e, principalmente, às operações, às asperezas e aos tempos sazonais dos frutos extraídos da terra. Encerra o poema um verdadeiro calendário dos dias faustos e infaustos para as atividades.

Os preceitos de Hesíodo cobrem desde o melhor momento para arar ou para a colheita até as vestimentas melhores para cada trabalho e estação. Ainda, as tarefas vão desde o corte da madeira no outono até a construção de ferramentas agrícolas, desde o cuidado dos bois e dos outros animais até o uso dos escravos, a composição marcada pelo transcorrer das estações.
Unindo os preceitos técnicos aos relativos aos dias faustos e infaustos se obtém um quadro claro da disposição ideal das atividades para os resultados melhores.

No Outono, Hesíodo prescreve arar, durante o período das chuvas, depois de preparar as ferramentas em casa: é necessário cortar a madeira melhor para a construção do arado 6 . O grito dos grous anuncia a chegada do inverno, e é necessário alimentar os animais nos estábulos. $\mathrm{Na}$ sequência dos dias, desde o começo de cada mês, o momento mais propício às atividades humanas é entre os dias 8 e $9.011^{\circ}$ e o $12^{\circ}$ dias propiciam a tosquia e as tarefas das colheitas, enquanto o $13^{\circ}$ não é propício à semeadura.

No inverno, Hesíodo convida o trabalhador a não sentar e se aquecer na frente da lareira, mas a seguir no trabalho. É detalhista na descrição do vestuário: uma capa e uma túnica comprida, calçados de couro forrados ${ }^{6}$. Especifica o tipo de costura, realizada em "nervo bovino" para as peles de cabra e, ainda, o uso de um chapéu. Nessa época do ano se realizam as atividades diplomáticas e se organizam casamentos.

Na primavera chega o momento de podar as parreiras ${ }^{6}$, em particular, o $13^{\circ}$ dia de todo mês é o melhor para dispensar cuidados às plantas. $\mathrm{A}$ primavera é, também, o momento certo para afiar as foices e colocar o jugo nos bois, operação para a qual o $27^{\circ}$ dia é o melhor.

O verão é apresentado como a estação durante a qual, nas horas mais quentes, é aconselhado descansar e se alimentar na sombra, mas também é o momento de bater o trigo no quintal, de preferência no sétimo dia do mês do meio, e guardá-lo nos vasos. São os dias apontados, também, para os cuidados do gado ${ }^{6}$.

No final do verão é o tempo da colheita da uva, que deve ser deixada ao sol por 10 dias, depois na sombra por 5 e, em seguida, guardada nos vasos.

Uma vez que os Erga tratam temáticas bem distantes do trabalho dos campos, Hesíodo é cuidadoso em suas indicações, apontando para 
uma necessidade de regular, normalizar as tarefas sazonais na direção de resultados faustos.

As referências sazonais e mensais são pontualmente oferecidas pelo poeta a partir do surgimento e do ocaso dos astros ou pelos sinais climáticos recorrentes, como as chuvas, que se tornam indicação específica para começar ou encerrar várias atividades ${ }^{6}$.

Hesíodo realça o valor do trabalho em si, expressando repetidas vezes o convite a não cair no ócio e ser tempestivo na hora certa.

Hesíodo é uma fonte preciosa para entender a ideologia dos pequenos proprietários de terra e, principalmente, para compreender a organização por traz da produção sazonal. As fontes iconográficas sobre o ciclo dos meses e das estações aparentam privilegiar, no âmbito grego, a jornada religiosa ao longo do ano ${ }^{7}$, tanto que a identificação de meses e estações desperta não poucas controvérsias, pois poucos elementos, ligados aos fatores climáticos, permitem distinções entre as imagens. O trabalho que gera os frutos e permite não somente a sobrevivência, mas uma organização social complexa privilegia o espaço poético da grande cosmogonia de Hesíodo mais que a iconografia, em que domina uma liturgia formal.

A indicação das operações e das tarefas no mundo rural aparece, na arte antiga, de forma ocasional, e as representações não se dispõem linearmente ao longo do ano, aparecendo de forma casual. Exemplo disso é o arco de Reims, do II-III século d.C., composto por 12 imagens, das quais restam $7^{7,8}$.

As imagens mostram homens e animais ativamente engajados nos trabalhos de semeadura, colheita, cenas pastorais e de cultivo. Tratam-se de meras ilustrações decorativas, sem uma sequência cronológica e, todavia, adquirem valor didático, pois remontam ao programa bucólico e de volta ao culto dos antepassados, instituída por Otaviano um século antes.

Com efeito, não refletem a simplicidade e a linearidade com que a Idade Média mostra o trabalho do homem no campo, pois as tarefas ligadas ao cultivo ou à criação e ao cuidado com os animais não se propõem como ponto focal dessas representações.

A Antiguidade legou à Idade Média uma variedade ampla de imagens fundamentadas, tanto na noção de personificação como de referências para as atividades ligadas aos ciclos sazonais, legado que será avaliado e modificado com base na nova experiência religiosa e social que permeia o período de maior presença dos ciclos dos meses ilustrados pelas atividades de produção do campo.

No âmbito da arte romana se encontram inúmeras contrapartidas de representações literárias às representações iconográficas dos meses.

Os Menologias Rústicas ${ }^{9}$ são inscrições sobre blocos verticais de pedra, com função de calendários. Neles são citadas as divindades que presidem cada mês, as datas das nonas e das festividades, em um tom econômico e seco. O elemento do trabalho no campo está bem presente em forma de preceitos e normas. Em dezembro prescreve-se a semeadura das favas, as queimadas em agosto e todas as outras atividades a serem desempenhadas ao longo do ano, ambientando as cenas na natureza. Tais inscrições se configuram como uma das premissas mais sólidas para a tipologia do calendário e das personificações dos meses na Idade Média. São o primeiro exemplo literário que inspira diretamente as representações iconográficas.

A literatura aparenta ser a área de maior identificação entre Antiguidade e Idade Média, em primeiro lugar por ela apresentar uma continuidade ausente na produção iconográfica. Em segunda instância, a Idade Média soube se confrontar, desde o começo, com os poetas clássicos de maior porte - Virgílio, Horácio, Ovídio - que, na descrição das estações e das atividades agrícolas relativas a elas remetem, diretamente, à experiência iconográfica.

Virgílio é o porta voz da política de Otaviano, que aponta para uma reabilitação do 
trabalho do homem e, principalmente, para uma volta às origens rústicas do povo romano. Uma das fragilidades do império romano era a redução contínua no número de pequenos proprietários terreiros, frequentemente engajados nas guerras. O latifúndio, fundado no trabalho escravo, com sua expansão contínua, também contribui com a redução da produtividade.

O projeto de reforma de Otaviano se articulava em volta da reconstituição de uma camada social que, por intermédio da gestão direta e constante das pequenas propriedades, reconstruísse um poderio produtivo com base mais sólida. A questão central não era, porém, somente de ordem econômica: tratava-se de estabelecer uma forte ligação do cidadão com a terra, para que ele a defendesse contra os invasores.

A terra e o labor improbus são o esqueleto das Georgicae, que sustentam a concretização do ideal cultural desenhado por Otaviano. Como poema, sua concepção o coloca à distância de um manual prático. Sua meta era restaurar valores ligados ao trabalho nos campos.

Os versos de 204 a 350 são dedicados ao calendário das tarefas do campo. Virgílio usa o moto dos astros e o andamento das chuvas para descrever a ordem das estações. Distingue as várias semeaduras que se realizam em épocas diversas: o malte no outono, com o linho e a papoula. Essa é também a estação para arar ${ }^{10}$, como no poema de Hesíodo. Na primavera, Virgílio aponta a estação para semear as favas ${ }^{10}$. Outras indicações para a semeadura ligadas a uma determinada época do ano são fornecidas ao longo dos versos. O poeta sugere a observação do céu para estabelecer os melhores dias para cada tarefa, assim que o trabalho seja melhor distribuído e os camponeses tenham tarefas a desempenhar também nos dias de chuva ou se aprontem para dias difíceis, na medida em que sabem interpretar os sinais.

Poucos anos antes das Georgicae, mas ainda no âmbito de uma política de volta às tradições proposta por Otaviano, Varrone escreve o De Re Rústica.
Depois de uma explicação sobre a divisão do ano e do cálculo em oito partes, em que ele deve ser dividido, de um mês e meio cada uma, Varrone especifica as atividades que devem ser realizadas na chegada da primavera: limpar as campinas e podar as plantas ${ }^{3}$. Entre o equinócio de primavera e a chegada do verão devem ser limpos os campos semeados e se deve quebrar a terra com os bois ${ }^{3}$. Em seguida, deve-se cuidar das parreiras e $a^{2} r^{3}$. Depois do solstício de verão é tempo de colheita. Quando terminar, será época de arar e semear lentilhas e legumes ${ }^{3}$.

Antes do equinócio de outono se corta a palha e se esmiúçam os campos arados ${ }^{3}$. Depois do equinócio se começa a semear, o que deve se encerrar antes do solstício invernal. Varrone afirma que é também o momento de semear as favas, alinhando-se aos preceitos dos Menologia, enquanto para Virgílio a época certa era a primavera.

O outono é o momento de colher a uva, e, logo em seguida, do cuidado com as árvores de frutos ${ }^{3}$, assim como o inverno, em que depois de podar as plantas se deve eliminar a água dos campos semeados e limpos ${ }^{3}$.

O tratado se encerra com o convite do autor a se ocupar também nos dias em que se deve permanecer em casa. Varrone utilizou materiais anteriores, tentando, em um contexto dialógico, mostrar a relevância da volta ao trabalho e à produção do campo.

\section{A Alta Idade Média entre florestas e comunidades}

O bosque, as áreas não cultivadas são o aspecto principal do ambiente medieval. Para o homem desse tempo, a Natureza inculta não carrega conotações negativas, pois é dela que consegue a maior parte de seu sustento e dos animais. Na floresta se recolhe a madeira para o aquecimento. Muita importância têm, para a alimentação dos porcos, os freixos e as faias, assim como o carvalho que, além de sustento aos porcos 
oferecia também material de construção. Da castanheira se usava a madeira preciosa, e o fruto representava, para muitas áreas, a base alimentícia.

O camponês alto medieval se ocupa de forma parcial do cultivo das terras, pois é também caçador, pescador e criador ${ }^{11}$. A comunidade rural representa uma espécie de ilha no meio de vastas áreas de floresta. Nesse espaço, protegido por cercas, as terras são cultivadas. Sobre elas, todavia, domina o exterior, em geral propriedade do senhor que, no decorrer do tempo, será arrancado à floresta e colonizado. A figura do camponês na Alta Idade Média é dúplice: ao lado das obrigações de colonização com o senhor, em força de um contrato ou de hábitos, associava-se a exploração da floresta e seus recursos.

É possível, a partir dos documentos, desenhar o panorama da produção de alimentos ligados ao cultivo dos campos e das hortas.

O setor dos cereais era fundamental, e o trigo era o produto mais apreciado, ainda que não o mais disseminado na Idade Média, seguido por centeio, aveia e cevada. Dois Capitulari emitidos em Frankfurt em 794 e em 806 fornecem indicações sobre o preço dos cereais e de seus derivados, principalmente o pão ${ }^{12}$.

Além dos cereais, havia o cultivo de legumes, em particular favas e ervilhas. A farinha dos legumes descascados compunha, frequentemente, os ingredientes do pão ${ }^{13}$.

Apesar de, a um primeiro olhar, se ter a sensação de certa variedade de produtos, a carestia e a miséria eram males endêmicos, por causa do escasso rendimento do solo cultivado. Nos anos piores, a colheita rendia por volta de $40 \%$ para o trigo e $38 \%$ para a cevada ${ }^{12}$.

Entre os produtos da época, devem ser lembradas as hortaliças, principalmente couve flor e nabos. O Capitulare de Villis cita a cenoura, além de alho porro, salsão, rabanetes e alho. Uma diretriz do concílio de Aix estabeleceu que os canônicos consumissem cebola somente nos dias de festa. Há vegetais que, conhecidos no mundo antigo, desaparecem da dieta medieval: alcachofras, aspargos e melão desaparecem do mapa da produção. Nas hortas são cultivadas também plantas têxteis, como cânhamo e linho, além das essências para as tinturas.

O cultivo da oliveira era difundido na bacia mediterrânea, mas o azeite era escasso e caro. Sua falta era substituída pelo óleo de nozes. Todavia, a Alta Idade Média privilegiava, para a alimentação, a gordura animal, como gordura e banha de porco, e reservava o azeite para a iluminação. As plantas medicinais ocupavam um amplo espaço. Um projeto de construção para o mosteiro de Saint Galles mostra uma parte de terreno reservada ao cultivo dessas essências. Um poema de Valafrido de Strabão, abade de Reichenau do século IX, Líber de Cultura Hortorum, trata amplamente das plantas medicinais que ele cultiva em seu jardim.

Sempre a partir das notícias oferecidas pelo Capitulare de Villis se conhecem as frutas cultivadas: maçãs, peras, ameixas, sorveiras, marmelos, amoras. O cultivo da uva se estendia muito mais para o norte do que hoje, tanto por razões climáticas como religiosas.

A criação de animais é atividade fundamental para a produção de alimentos, tanto de forma direta como indireta. Havia criação de bovinos, que forneciam a principal força de trabalho alternativa ao homem e o leite, do qual se produzia o alimento de base da inteira Idade Média: o queijo. Somente as cabeças velhas ou deformes eram abatidas. Diferente era o destino dos porcos, que ocupavam o lugar mais importante do setor da criação: sua carne era a mais utilizada na época, e os cuidados necessários com a criação eram poucos, pois ocupavam as florestas, onde encontravam farta alimentação.

Ovinos e equinos ocupavam um lugar secundário na economia alto medieval, ainda que dos primeiros se obtivesse leite e lã e os segundos se destinassem ao transporte.

Uma atividade fundamental era a pesca, principalmente de água doce em áreas afastadas 
do litoral, pela impossibilidade dos transportes. Pântanos, rios e lagoas estavam à disposição de quem quisesse, e toda propriedade possuía um pesqueiro artificial, cujos produtos eram reservados ao senhor.

A caça tornou-se cada vez mais uma atividade reservada à nobreza, que desde o século IX se torna defensora da floresta, assediada pelas necessidades da colonização. Ursos, javalis e veados eram amplamente presentes, assim como aves e pequenas presas ${ }^{14}$.

Pelos inventários dos mosteiros altos medievais verificava-se a escassez de metal, necessário para construir ferramentas mais eficientes. Apesar do uso de ferramentas pouco eficazes, a colonização da floresta avançava. O arado tinha um vômer e asas simétricas, e todo camponês podia fabricar um, mas sua eficácia era tão limitada que a tarefa de abrir e revirar a terra de maneira mais profunda cabia aos homens que completavam o trabalho do arado com marretas. A invenção do arado assimétrico, provavelmente por volta dos séculos IX-X, teve consequências primárias sobre a chamada revolução agrária. Era dotado de um vômer mais desenvolvido de um lado, que cortava os torrões horizontalmente, e era completado com um eixo oblíquo.

No âmbito da organização rural do território grande peso tiveram as estruturas eclesiásticas. Já no $V$ século a formação de mosteiros constituiu um núcleo alternativo às cortes e aos centros urbanos $^{15}$. Muitos dos maiores centros abaciais surgiram pela obra de monges andarilhos, em lugares ermos que se tornaram marcos de eventos milagrosos, portanto lugares sagrados. Tais lugares eram, com frequência, ruínas de antigas cidades, ricas em materiais que podiam ser reutilizados ${ }^{15}$. Erigiram-se, assim, as fundações dos futuros centros de riqueza, de poder e de prestígio, como as abadias de Corbie ou de Fulda, mosteiros exclusivos reservados à nobreza e aos senhores.

A abadia era um microcosmos em que vigia uma organização autônoma, em que o trabalho era confiado ao camponês locatário e a floresta estava à disposição de todos, em troca de um censo. A partir de ricas doações os patrimônios abaciais se tornaram bastante extensos, e aonde não chegavam as doações, se conseguiam as injunções jurídicas. Assim foi o caso da comunidade de Flexum, cujos moradores se opuseram ao poderoso mosteiro de São Silvestro de Nonantola. Os monges, com efeito, queriam eliminar um direito adquirido de pesca e pasto. O tribunal acolheu o pedido do cenóbio, que obteve, assim, o controle efetivo da área ${ }^{16}$.

É exatamente no âmbito dos mosteiros que, a partir do final do século VIII, se encontra uma nova produção de calendários, tanto na literatura como na iconografia. A representação visual do ciclo dos meses em suas formas clássicas se contamina, cada vez mais, com os ecos literários da tradição poética e didática, dedicando cada vez um espaço maior ao trabalho voltado para a produção de alimentos em uma sociedade cada vez mais cultivada.

Na Idade Média, o ano começava no Natal: as datas essenciais entrelaçavam as necessidades do trabalho no campo com festividades religiosas. No mês de Março eram realizadas algumas semeaduras, chamadas cereais de Março. Diferenças climáticas de um lugar para o outro incidiam, obviamente, sobre o período exato das realizações; por isso, na Itália a poda dos vinhedos acontecia já em fevereiro, enquanto nos paises ao norte dos Alpes eram reservadas para o mês seguinte. A primavera coincidia com a volta aos pastos externos do gado. Em junho - na Itália - e julho/agosto - na França - se cortava e guardava o feno e se tosquiavam as ovelhas. Setembro ou outubro eram os meses da colheita da uva e, ao mesmo tempo, da semeadura invernal. Nessa época a alimentação para suínos era mais farta ${ }^{17}$.

É com base nessa divisão do ano que se estruturam os calendários: a representação de uma ética positiva do trabalho filtra da literatura antiga para encontrar as condições sociais e econômicas de uma realidade subtraída à floresta para a colonização do terreno. As mudanças iconográficas permitem conhecer as etapas desse deslocamento de uma economia de subsistência, fragilmente 
atrelada ao ciclo sazonal, para uma economia fortemente atrelada ao cultivo, que precisa organizar um saber técnico para que a riqueza do campo seja maior, imagens ideológicas de uma sociedade ideal, carregadas de valores augurais e capazes de designar ideais sociais.

\section{Considerações sobre herança literária e iconográfica}

Uma questão relevante na constituição de calendários portadores desses valores reside no fato de serem uma produção cultural eclesiástica que expressa o calendário popular dos camponeses. É uma expressão que ultrapassa o dualismo de uma visão ideológica e sagrada do tempo - que reconhece as festividades e se fundamenta em cálculos astronômicos - e de uma noção popular do volver do ano, em que os eventos podem ser previstos pela reiteração da experiência.

A cultura camponesa é serial, porque na sua base se encontra o trabalho sazonal no campo, cíclico, repetido meta-historicamente, especializado de maneira definida em cada mês e sempre igual a si mesmo ${ }^{18,19}$. A partir da repetição representativa abre-se a possibilidade de criar uma tipologia dos meses fundada nessa repetição do trabalho no volver do ano, tanto na literatura como na iconografia. Como modelo dessa representação, muito conservadora e, ao mesmo tempo, inovadora, podem-se citar 12 versos atribuídos a Bede, o Venerável, que listam, secamente, as tarefas necessárias para o bom rendimento do trabalho:

Januarus: poto / Februarius: ligna cremo / Martius: de vite supérflua demo / Aprilis: do gramen gratum / Maius: mihi servit flos / Junus: mihi pratum / Julius: foenum declino / Augustus: segetes tero / September: vina propino / October: sêmen humo jacto / November: mihi pasço sues / December: mihi macto ${ }^{20}$.

As implicações com a literatura clássica transparecem constantemente nas produções de ciclos de meses do começo do século IX. É preciso lembrar que quando a iconografia dos meses reaparece, ela se destina aos únicos interlocutores capazes de decodificá-la, ou seja: aqueles que possuem uma cultura escrita. Produtores e receptores coincidem, portanto, na figura dos monges, razão pela qual a produção literária é maior que a iconográfica, contrariamente ao que acontece depois dos séculos X-XI.

O cultivo organizado das terras como forma privilegiada de produção de alimentos ainda não era uma realidade. Somente com a revolução agrária no século XI o papel do camponês como produtor de alimentos, enquanto membro de um grupo organizado em volta das tarefas ordenadas pelo tempo do campo, se torna modelo explícito ${ }^{21}$.

Na reorganização feudal do território e da produção dos bens primários do campo, os camponeses adquirem um papel oficial, dotado de representações do trabalho, didáticas e normativas, mas, ao mesmo tempo, apreciativa e de inclusão na comunidade cristã. A formação de novas e mais produtivas propriedades no século $\mathrm{XI}$ é destinada a fornecer bases de riqueza destinadas a futuros investimentos em atividades urbanas e mercantis. Apesar da profusão de manuscritos iluminados dessa época, poucos, ainda, são os exemplos de ilustração de meses ativamente envolvidos nas tarefas e nos cuidados do campo. A época da maior difusão dessas imagens é a mesma das grandes catedrais, enriquecidas de imagens sagradas e profanas, ainda é distante e se torna tangível graças a essas riquezas que confluem no mundo urbano em afirmação, e se abrem no século XII.

Quando o modelo do camponês é representado ativamente envolvido na produção de alimentos, sua função de membro do corpo social organizado em volta do ciclo que sustenta a todos é reconhecida. O camponês, que agrega seu trabalho de forma disciplinada ao longo dos meses, se encontra representado no espaço religioso como único representante do trabalho legitimo em um mundo em que mercadores e homens de negócios começam a se perfilar. Essas figuras, oriundas do próprio mundo urbano, representam 
uma ameaça desestabilizadora de equilíbrios sociais, não se sustentando, suas atividades, em uma tradição ética e religiosa positiva ${ }^{22,23}$.

Essa força desagregadora se combate no plano teológico, colocando as atividades urbanas como fruto do demônio, no exercício das quais será inevitável o pecado capital. Entre a população iletrada se combate a partir do desenvolvimento e do uso de modelos iconográficos que reforcem a identidade do trabalhador com a ética criadora de Deus: porquanto o trabalho do camponês fosse desprezado enquanto humilde, acabava encabeçando, nessa disputa teológica transferida aos olhos dos fiéis, a escada de valores, pois era quem mais imitava a obras de Deus, produzindo os frutos da terra.

\section{O equilíbrio ideal dos meses de Benedetto Antelami}

A partir do século XII se estabelecem dois níveis de representações das personificações dos meses. O primeiro é a observação do trabalho, com a consciência da mudança produtiva que aconteceu; assim, a ampliação das terras cultivadas, a escavação de canais, o desmatamento estão presentes na própria escolha de representar incessantemente o trabalho agrário, em lugares de culto acessíveis a todos os olhares, e não mais reservados a uma elite letrada, como antes. A representação do ciclo produtivo de alimentos se revela um ato ideológico, que aponta a profunda mudança da realidade produtiva.

Por outro lado, encontra-se a leitura alegórica das eternas mudanças sazonais e dos meses, como se encena de maneira evidente exatamente no ciclo dos meses do batistério.

Um conjunto particularmente interessante de personificações dos trabalhos dos meses é atribuído a Benedetto Antelami e à sua escola24 . É constituído pelo ciclo em baixo relevo no arco do portão principal da Catedral de Parma, pelo ciclo de estátuas do batistério da mesma cidade e, ainda, pelos relevos no portal da Catedral de
Cremona e os da Catedral de Ferrara, além do ciclo de Borgo San Donnino.

O ciclo mais relevante do conjunto é o grupo de estátuas reunidas no batistério de Parma que se encontra na galeria superior da edificação, ainda que a presença de entalhes nas bases das esculturas aponte para uma provável mais em baixo, em correspondência com a decoração exter$n a^{25}$. Criava-se uma continuidade de leitura entre o exterior e o interior sobre os temas da vida e da morte física e espiritual do homem mas, acima de tudo, da função positiva que o trabalho, entendido como única forma de expiação concedida ao homem durante sua vida, adquiria.

Ao resgatar a antiga tradição romana, que apresentava o início do ano em Março, portanto na época do renascimento da primavera, o Antelami torna cristão esse elemento de renascimento. Março assopra em um corno, com os cabelos agitados pelos ventos. Abril, que segue, é um rei, coroado de flores, mais exatamente lírios; ambas as representações se enquadram em uma tradição iconográfica romana. Maio se apresenta como cavalheiro com uma pequena foice na mão. Junho corta o trigo, Julho o bate, usando uma dupla de cavalos. É uma imagem nova de técnicas novas, pois anteriormente essa atividade era realizada e representada - por homens.

Agosto é um homem que constrói barris, e Setembro colhe a uva. Outubro semeia, no fundo se vê um carvalho, alusão à estação em que a comida é farta para os porcos. O animal, aqui, está presente por metonímia. Novembro colhe os nabos. Segue Dezembro, que corta a madeira para o inverno. Janeiro, bifronte, elegantemente vestido, se esquenta com a fogueira. Por último, Fevereiro, que se prepara a cavar na terra.

Os meses desse ciclo apresentam algumas particularidades interessantes, um requinte profundo na expressão dos valores éticos e normativos que ilustram a produção ideal do campo. Antelami revela, em primeiro lugar, o conhecimento da tradição e da cultura clássica, tanto na escolha de iniciar o ciclo com o mês de Março, como na escolha da estação da primavera, com semblante 
de Flora ou, ainda, no Janeiro como Janus. A habilidade de Antelami vai além. Observando as esculturas a partir de Fevereiro percebe-se que, até o mês de Outubro elas possuem um semblante jovem. Desse ponto, até Janeiro, os meses têm semblante mais maduro, com barba, mais sobriamente vestidas, apontando para o destino comum do declínio humano e das estações para o inverno.

A escultura que personifica a estação invernal é dividida em duas partes, assim como o rosto bifronte de Janus, na passagem entre uma natureza adormecida e seu despertar, entre a vida e a morte: o lado voltado para Dezembro é vestido e, no fundo, aparece um galho seco. O lado esquerdo, voltado para a primavera, é bem menos vestido e o galho tem folhas ${ }^{25}$.

Dado primário desse ciclo, que mistura o ritmo clássico da divisão do ano com as sugestões literárias, é o enobrecimento do camponês e de seu papel de produtor, revelado pelo trabalho humano das figuras, visualização da literatura poética e didática dos Antigos.

Exemplo disso é o mês de Novembro, no qual o carvalho revela que o artista não esquece, entre as tarefas do mês, o cuidado com a engorda do porco, mas não deseja rebaixar o registro hierático mostrando os animais pastando.

O enobrecimento do trabalho se percebe na proximidade fluida entre os meses de descanso invernal e aqueles de trabalho, retratos nobres de camponeses. Janeiro é vestido como um senhor, e verifica-se como esse mês configura uma iconografia ligada aos banquetes, transformando-se em cena de vida cortês, como será visto. O mesmo se aplica ao mês de Abril com suas flores, aqui ilustrado com uma coroa, como um rei. Maio, por sua vez, foi objeto até tempos recentes de disputas acadêmicas, pois segura uma foice, como um camponês, mas cavalga como um cavalheiro, somando as qualidades de nobre e camponês ${ }^{25}$.

Esse ciclo é considerado obra de ruptura iconográfica, mesmo na continuidade da tradição, e de integração visual das formas de interpretar e representar os meses na fronteira entre literatura e iconografia. Basta comparar o ciclo do batistério com aquele, um pouco mais antigo, do portal da Catedral: as figuras que podem ser assimiladas nas duas séries são Janeiro e Dezembro. Agosto e Setembro apresentam a mesma iconografia, mas com diverso estilo. Abril e Maio, com temas parecidos, apresentam escolhas diferentes: o primeiro não é coroado, o segundo mostra um homem a pé com a foice na mão, conduzindo o cavalo. Falta aquela mistura sutil que combina o enobrecimento das atividades humildes da vida humana.

Em geral, pode-se afirmar que as representações dos meses do século XII alcançam, no ciclo de Antelami, uma configuração não desvinculada da tradição mas fortemente inovadora nos conteúdos. A ampla difusão nos espaços sagrados de maior visibilidade reflete sobre o destino do homem que nasce e morre, sua ressurreição espiritual no batismo, mas, principalmente, sobre o ciclo imutável do tempo como produtor ideal de fartura, garante de estabilidade social.

São do século XII, em suma, a difusão e a renovação dos temas e dos modelos iconográficos que ilustram o ciclo de produção alimentar a partir da representação do trabalho humano do campo, considerando o valor de punição bíblica que o trabalho carregava. O fato de as representações se encontrarem em espaços de grande visibilidade é indicador de uma mudança radical na interpretação da fadiga e do esforço necessários à produção alimentar.

\section{As Trés Riches Heures}

O ciclo dos meses das Trés Riches Heures é uma fonte particularmente importante para ilustrar a ideologia das representações do camponês a partir do século XIII. Nesse momento ainda há poucos exemplos de figurações de camponeses em posturas preguiçosas ou ridículas: na época, ainda não se formalizou a chamada sátira do vilão, representada, em última análise, pela figura do Jeca Tatu no Brasil do século XX. 
As 12 miniaturas do calendário, realizadas pelos irmãos De Limbourg, foram encomendadas pelo duque de Berry e realizadas em grande parte entre 1402 e 1416, quando foram interrompidas. Retomadas em 1489, foram concluídas por Jean Colombe, sob encomenda do duque Carlos de Sabóia.

As representações se moldam na tradição das tarefas mensais do campo, mas mudanças de grande porte se encontram nas composições ${ }^{26}$. Viu-se que as ocupações que marcam um ciclo de produção alimentar agrário se difundem, em ampla escala, no século XII, em seguida aos efeitos das inovações técnicas no campo, que alcançaram a Europa inteira, durante aquela que Marc Bloch definiu como "segunda Idade Feudal". É o século em que a ideologia da sociedade tripartida se define, identificando seus membros como Orantes, Bellantes e Laborantes ${ }^{27}$. Os ciclos dos meses se focalizam, essencialmente, nas duas ordens laicas da sociedade, os bellantes, compostos pela nobreza, e os laborantes, identificados, em contraposição às atividades urbanas, com os camponeses produtores. Excluem, portanto, a ordem dos orantes. Aparecem com destaque nos espaços sagrados e começam a decorar âmbitos mais privados, como os saltérios e os livros de oração. Estes últimos representam um espaço reservado para aqueles que possuem cultura e riqueza, ou seja, desde o século XII, além dos religiosos, também os nobres e os ricos burgueses: aqueles que não se dedicavam ao trabalho, mas que dele dependiam para carregar suas ricas mesas, mas para os quais não havia envolvimento direto com o trabalho do campo.

Já na primeira ilustração, Janeiro, se percebe o distanciamento ideológico entre as representações voltadas para os membros trabalhadores da comunidade de fieis, cujo exemplo paradigmático é o ciclo de Antelami, e as ilustrações reservadas aos olhos de uma nobre elite. No lugar da representação de um homem que se aquece ao calor do fogo, aqui se ilustra uma cena de banquete vivaz, presenciado pelo próprio duque de Berry, cercado por variadas personagens que compõem sua corte. Contraposta a esse estilo de vida nobre e agradável segue a imagem de Fevereiro, na qual se ilustram algumas cenas de vida camponesa: em um interior, três mulheres se aquecem na frente de uma lareira incomparavelmente menor do que aquela da cena anterior, mas, acima de tudo, as três figuras se apresentam com posturas vulgares, com as saias levantadas acima dos joelhos e as anáguas à vista. Isso sugere uma intenção satírica na representação das camadas populares $^{28}$. Na mesma miniatura encontram-se outras três figuras, ocupadas no exterior da casa, uma assoprando sobre as mãos, outra cortando madeira e a terceira conduzindo uma mula.

Na miniatura de Março a cena ilustrada é de aradura; se observa também a poda das parreiras. O imaginário cortês é bem marcante no mês de Abril. Aqui, o homem carregado de flores é substituído por uma cena de amas e cavalheiros no jardim, empenhados em conversas e colhendo flores. A cena de Maio, também, abandona as referências às fadigas camponesas para retomar a imagem do cavalheiro. As figuras presentes são, todavia, numerosas, todas ricamente trajadas e ornadas. As cenas seguintes constroem, novamente, uma dialética com as imagens da vida de corte: Junho e Julho, com as cenas de colheita, apresentam o traço mais antitético nos trajes modestos e reduzidos. Agosto mostra a caça como falcão, e em Setembro voltam os trabalhos, com a cena da colheita da uva. Um dos camponeses vira de costas para nós, particular presente no mês de Março também: trata-se de um particular que pode se atrelar à sátira do vilão, especialmente porque o sabor "pitoresco" da ilustração se reforça pela presença das roupas íntimas e das meias caídas com negligência. Não há cenas em que os membros das outras camadas sociais apresentem a mesma postura de desleixo ${ }^{29}$. A cena de Outubro é a semeadura, enquanto Novembro se ocupa da alimentação dos porcos. A última representação, o mês de Dezembro, oferece uma elaboração nobre do tema da matança do porco, traduzindo-a em uma cena de caça ao javali30. A referência à ocupação principal do mês é preservada, criando 
um nítido contraste entre a caça e os criadores de porco ${ }^{28}$.

Posto que esse ciclo apresente conotações ideológicas claras, deve se manter separada a noção de realismo, enquanto atenção ao dado natural da representação frequentemente cruel do camponês.

Não se podem interpretar cenas iconográficas na convicção que elas ilustrem, simplesmente, os dados e os modos de vida de uma época. Seria impensável esperar que quem possuía obras como as Trés Riches Heures se identificasse com os trabalhadores: existe, sem dúvida, uma forte idealização que beneficia os proprietários dessas obras.

Interessa, aqui, pensar as camadas semânticas de uma iconografia ligada à produção de alimentos, presente na sequência dos meses: o arador.

Pode-se referir a uma imagem paradigmática de arador, contida no Saltério de Luttrell, criado para Sir Geoffrey Luttrell entre 1310 e 1345 . Os elementos que a compõem a assimilam a cenas similares em ciclos. Ao mesmo tempo, como imagem isolada, favorece uma análise mais pontual.

O arado alcançou uma importância maior pelas inovações técnicas que o tornaram mais eficaz. Sua difusão é testemunhada por multíplices ilustrações nas quais aparece, desde os ciclos dos meses às cenas hagiográficas ${ }^{31}$, e logo adquire valor simbólico religioso: a cena da aradura se torna emblema oficial da ordem dos Orantes, cena em que o campo é a alma, o arado é o pregador e os bois as Escritas Sagradas ${ }^{32}$. O ato de trabalhar a terra, como se disse, é a única atividade manual do homem digna de comparação com a obra criadora de Deus, portanto, por um longo tempo, o trabalho se identifica com a agricultura. Observando o arador do saltério de Luttrell se percebem particulares interessantes: o arado é apresentado com grande cuidado à estrutura técnica, de forma que não se trata de uma reprodução mais ou menos aproximada da ferramenta, mas de um exercício analítico comparável a um desenho técnico, com a reprodução de cada parte acompanhada por seus nomes em latim.

A importância dessa imagem reside em sua afinidade com as personificações dos meses. A figura do arador é, em geral, apresentada com os trajes e a postura sóbrios e elegantes ao excesso, comparado com outras imagens de camponeses. É uma particular que se encontra também na miniatura de Março das Trés Riches Heures, na qual a atenção aos trajes é notável: aqui também estão um cuidado maior que nas outras iluminuras: a túnica está abotoada, os pés calçados e há um elegante barrete. Aparentemente, os aradores fogem à sátira do vilão, se aproximando muito mais da alegoria que envolve sua representação.

Inúmeras são as fontes bíblicas que se referem à aradura dos campos: Provérbios 20-4, Coríntios 9-10, Isaias 28.24-9, e é com base nisso que a imagem do Salvador como cavalheiro é substituída pela do arador. Não se torna, portanto, possível representá-lo em posturas vulgares ou ridículas, até em ambientes de forte conotação ideológica nobre, pois a imagem simboliza o valor da nobreza do próprio trabalho. O arador e, em seguida, o semeador, são lugares comuns nos sermões dos pregadores, pois quem trabalha com suas mãos produzindo frutos é abençoado ${ }^{32}$.

Nas miniaturas que decoram os livros de orações a relação de subordinação entre o senhor, proprietário terreiro, e o camponês é construída paralelamente à relação entre a fadiga humana imposta por Deus e o próprio Deus. A necessidade de sulcar e virar a terra assume as funções mística e real de subordinação às hierarquias celestes e terrenas. Dessa forma, a imagem dos Laborantes resulta reforçada e justificada. O suor do camponês é compensado pelos frutos das colheitas e, ao mesmo tempo, com o alcance da beatitude do Paraíso.

O senhor, por outro lado, encontra suas recompensas na fartura das mesas postas, tema cada vez mais presente nas iluminuras dos meses e, com as mesmas características, no saltério de Luttrell, no qual se encontram Sir Geoffrey sua 
família inteira e dois hóspedes dominicanos. A cena divide, claramente, o espaço do senhor daquele dos servos. Ao lado dessa miniatura outra, com a imagem das cozinhas, na qual aparece, novamente, o trabalho dos humildes.

Os nobres banqueteiam em um ambiente à altura de seu status, enquanto os humildes oferecem seus serviços ao senhor terreno e, ao mesmo tempo, ao Senhor celeste.

Pode-se observar que, entre os séculos XIII e $X V$ as iluminuras dos manuscritos iluminados encomendadas pelos membros da nobreza são referenciais de uma cultura cortês, em boa medida no registro das representações de trabalho e de descanso: nas primeiras, o arador encarna o perfeito agricultor virtuoso, que sustenta o resto da sociedade e que, portanto, é ideal isento da sátira do vilão, tornando-se o elo entre a nobreza e o povo do mundo rural.

Outra nota pode ser registrada: os camponeses dos ciclos dos meses, responsáveis pela fartura na mesa do senhor, podem ser representados em sua sujeição ao senhor: nunca, todavia, revelam sinais de indigência. Uma homenagem à grandeza dos senhores que, idealmente, são magnânimos com seus trabalhadores. A história, porém, fala de crises alimentares contínuas, que despovoavam o campo rumo às cidades que não conseguiam sustentar o peso de uma população miserável e esfomeada.

\section{CONSIDERAÇÕES FINAIS: DO CAMPO PARA A MESA}

A imagem do mundo rural entre Idade Média e Idade Moderna muda seu aspecto. A sátira do vilão legou à humanidade imagens literárias e iconografias marcadas pela vulgaridade e pela esperteza do camponês. E a relação entre cidade e campo colocou o segundo em posição cada vez mais subordinada. A cidade é o lugar do mercado, o lugar da referencia política. É o espaço fechado, protegido pelos muros que encerram os moradores, protegendo-os contra as invasões. É nessa perspectiva que se estabelece a nova dimensão humana que perde, aos poucos, sua dependência do ritmo das estações e dos meses que constituíram uma ampla parte do repertório iconográfico que fala de fartura na produção alimentar.

A escassez alimentar, à qual a população estava acostumada, fez com que os aumentos da produção agrícola se transformassem em experiências estimulantes de sugestão visual. No espaço urbano humanista e renascentista as cenas de mercado aparecem integradas aos temas bíblicos, até se tornarem um gênero autônomo. Também foi o caminho das cenas de cozinha que, com as primeiras, confluem na grande tradição tardo-maneirista e barroca das Naturezas Mortas, a última grande celebração de fertilidade, virtude e moralidade que a arte ocidental atribuiu aos frutos da natureza e do trabalho humano.

\section{REFERÊ NCIAS}

1. Male E. The gothic image: religious art in France. London: Harper \& Row; 1990.

2. Huizinga J. L'autunno del medioevo. Roma: Newton; 1992.

3. Varrone. Opere. Torino: Einaudi; 1974.

4. Singleton CS. La poesia della Divina Commedia. Bologna: II Mulino; 1978.

5. Bernabó M. La cacciata dal Paradiso e il lavoro dei progenitori in alcune miniature medievali. In: Atti del I Congresso di storia della miniatura italiana: la miniatura italiana in etá romanica e gotica; magg 1978; Italia, Cortona; 1978.

6. Hesíodo. Obras. Torino: Einaudi; 1977.

7. Webster JC. The labors of the months in antique and medieval art. New York; 1938.

8. Esperandieu EJ, editor. Recueil general des basrelieves de la Gaule Romaine. Paris: Ministere de I'Instrution Publique; 1933. Collection de documents inedits sur I' Histoire de France n.3681.

9. Henzen W, editor. Corpus Inscritiones Latinorum II: Brephols; 1876.

10. Virgílio. Tutte le Opere. Firenze: Sansoni; 1966.

11. Fumagalli V. L'uomo e l'ambiente nel Medioevo. Roma-Bari: Laterza; 1992.

12. Dhondt J. L'Alto Medioevo. Milano: Mondadori; 1990. 
13. Flandrin JL, Montanari M, organizadores. História da alimentação. São Paulo: Estação Liberdade; 1998.

14. Villani C. Consuetudini di caccia negli Annales Regni Francorum. In: Andreolli B, Montanari M, organizadores. Il bosco nel Medioevo. Bologna: CLUEB; 1988.

15. Fumagalli V. La pietra viva: cittá e natura nel Medioevo. Bologna: II Mulino; 1988.

16. Tiraboschi G. Storia della augusta Badia di Nonantola. Modena; 1785. v. 2, p.1824-5.

17. D'Haucourt G. A vida na Idade Média. São Paulo: Martins Fontes; 1994.

18. Bloch M. La societá feudale. Torino: Einaudi; 1979.

19. Le Goff J. Tempo della chiesa, tempo del mercante. Torino: Einaudi; 1977.

20. Migne JP. Patrologia latina cursus completus. Paris: Garnier: 1866. v. 5, 90

21. Barberis C. Le campagne italiane: da Roma antica al settecento. Roma-Bari: Laterza; 1997.

22. Le Goff J. I riti, il tempo, il riso: cinque saggi di storia medievale. Roma-Bari: Laterza; 2001.

23. Le Goff J. L'Immaginario medievale. Milano: Mondadori; 1993.
24. Quintavalle AC. Benedetto Antelami. Milano: Electa; 1990.

25. Frugoni C. I mesi antelamici del Battistero di parma. Parma: Battei; 1992.

26. Pacht O. Early Italian nature studies and the early calendar landscapes. J Warburg Courtauld Inst. 1950; 13:13-47.

27. Duby G. Lo specchio del feudalesimo. Roma-Bari: Laterza; 1989.

28. Alexander J. Labeur and Paresse: ideological representations of medieval peasant book. Art Bull. 1990; 20(2):436-52.

29. Schmitt JC. II gesto nel Medioevo. Roma-Bari: Laterza; 1999.

30. Baltrusaitis J. II Medioevo fantástico: antichitá ed esotismi nell'arte gótica. Milano: Adelphi; 1993.

31. Romano G. Studi sul paesaggio. Torino: Einaudi; 1991.

32. Camille M. Labouring for the Lord: the ploughman and the social order in the Luttrell Psalter. Art History. 1987; (10):423-54.

Recebido em: 14/8/2009 Aprovado em: 2/2/2010 